\section{Brachial plexus block with a new local anaesthetic: 0.5 per cent ropivacaine}

Rosemary Hickey MD, ${ }^{*}$ Kenneth D. Candido MD, $\dagger$ Somayaji Ramamurthy MD, ${ }^{*}$ Alon P. Winnie MD, $\dagger$ Janna Blanchard MD,* Syed M. Raza MD, $\dagger$ Joan Hoffman RN MSN, ${ }^{*}$ Zia Durrani MD, $\dagger$ Robert W. Masters MD $\dagger$
A new local anaesthetic, ropivacaine hydrochloride, was used in a concentration of 0.5 per cent in 32 patients receiving a subclavian perivascular block for upper extremity surgery. One group $(n=15)$ received 0.5 per cent ropivacaine without epinephrine and a second group $(n=17)$ received 0.5 per cent ropivacaine with epinephrine in a concentration of $1: 200,000$. Anaesthesia was achieved in 87 per cent of the patients in both groups in all of the $C_{5}$ through $T_{1}$ brachial plexus dermatomes. Motor block was profound with 100 per cent of patients in both groups developing paresis at both the shoulder and hand and 100 per cent developing paralysis at the shoulder. There was a rapid initial onset of sensory block (a mean of less than four minutes for analgesia) with a prolonged duration (a mean of greater than $13 \mathrm{hr}$ of analgesia). The addition of epinephrine did not significantly affect the quality or onset of sensory or motor block. The duration of sensory block was reduced by epinephrine at $T_{1}$ for analgesia and at $C_{7}, C_{8}$, and $T_{1}$ for anaesthesia. The duration of sensory block in the remaining brachial plexus dermatomes as well as the duration of motor block was not effected by epinephrine. There was no evidence of cardiovascular or central nervous system toxicity in either group with a mean dose of $2.5-2.6 \mathrm{mg} \cdot \mathrm{kg}^{-1}$ ropivacaine.

\section{Key words}

ANAESTHETICS, LOCAL: ropivacaine; ANAESTHETIC TECHNIQUES: regional, brachial plexus.

From the Department of Anesthesiology, *University of Texas, Health Science Center at San Antonio, 7703 Floyd Curl Drive, San Antonio, Texas 78284, and the Department of Anesthesiology, †University of Illinois, College of Medicine at Chicago, 3200 West, 1740 Taylor Street, Chicago, Illinois 60612 .

The study was supported by a grant from Astra Alab AB and was conducted at Audie L. Murphy Memorial Veteran's Administration Hospital (San Antonio, Texas), Medical Center Hospital (San Antonio, Texas), West Side Veteran's Administration Hospital (Chicago, Illinois), and University of Illinois Hospital (Chicago, Illinois).

Address correspondence to: Rosemary Hickey, The University of Texas, Health Science Center at San Antonio, 7703 Floyd Curl Drive, San Antonio, Texas 78284-7838.
Afin de permettre une intervention chirugicale sur le membre supérieur, nous avons fait chez 32 patients un bloc périvasculaire par approche sous-clavière en utilisant une solution de 0,5 pour cent d'hydrochlorure de ropivacaine. Cette solution était employée seule (groupe I, $n=15$ ) ou enrichie d'adrénaline d 1:200 000 (groupe $I I, n=17$ ). Nous avons obtenu une anesthésie de tous les dermatomes entre $C_{5}$ et $D_{1}$ chez 87 pour cent des patients des deux groupes. Le bloc moteur était intense avec une paralysie de l'épaule et au moins une parésie de la main chez tous les patients. Le bloc sensitif s'installait rapidement et durait longtemps (l'analgésie survenait en moins de quatre minutes et durait plus de 13 heures en moyenne). L'addition d'adrénaline n'eut en général pas d'effet sur la latence, la qualité et la durée des blocs moteurs et sensitifs sauf celui d'abréger l'analgésie dans le territoire de $D_{1}$ et l' anesthésie dans celui de $C_{7}$ a $D_{1}$. Avec des doses moyennes de 2,5 et $2,6 \mathrm{mg} \cdot \mathrm{kg}^{-1}$ de ropivacaïne, nous n'avons noté de signe de toxicité centrale ou cardiovasculaire dans aucun des deux groupes.

Ropivacaine is a new local anaesthetic with a chemical formula similar to that of other amino amides in clinical use (Figure 1). The physical properties of ropivacaine are listed in Table I. In vitro studies have demonstrated that ropivacaine is a potent blocker of $\mathrm{A} \delta$ and $\mathrm{C}$ fibres (pain fibres). ${ }^{1}$ Preliminary animal studies have also shown that ropivacaine is an effective local anaesthetic for infiltration, epidural, spinal, and brachial plexus anaesthesia. ${ }^{2,3}$ In a guinea pig model of brachial plexus block Akerman $e t$ al. demonstrated that ropivacaine was similar to bupivacaine in terms of onset and duration of sensory block and frequency of motor block. ${ }^{2}$ It has been reported to be less toxic than bupivacaine but more toxic than lidocaine..$^{2,4}$ No previous studies have evaluated ropivacaine for brachial plexus anaesthesia in man. The purpose of this study was to determine the efficacy and safety of 0.5 per cent ropivacaine with and without epinephrine in patients receiving subclavian perivascular brachial plexus blocks. The rapidity of onset as well as duration of sensory and motor block were also determined. 


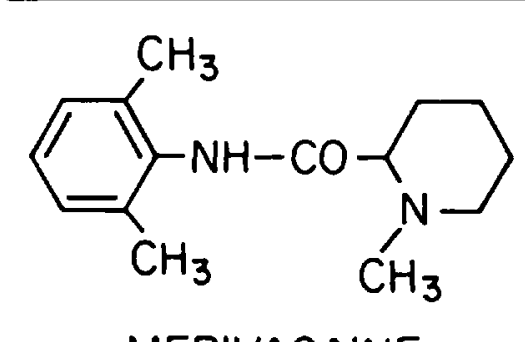

MEPIVACAINE<smiles>CCCN1CCCC[C@H]1C(=O)Nc1c(C)cccc1C</smiles>

ROPIVACAINE

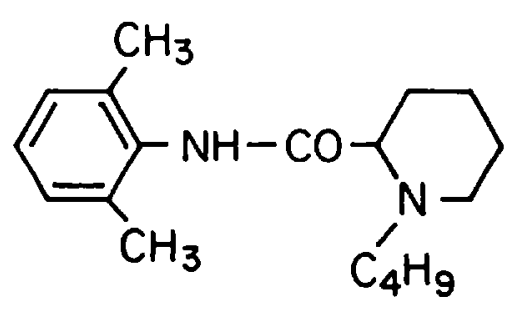

BUPIVACAINE

FIGURE 1 The chemical formula of ropivacaine resembles that of the amino amides mepivacaine and bupivacaine.

TABLE I Physical propertics of ropivacaine

\begin{tabular}{ll}
\hline Molecular weight & 328.89 \\
Generic name & Ropivacaine hydrochloride monohydrate \\
Laboratory name & LEA 103 \\
Active form & s isomer \\
pKa & 8.07 \\
Protein binding & $94 \%$ \\
Partition coefficien** & 147 \\
\multicolumn{1}{c}{ (lipid solubility) } & \\
\hline
\end{tabular}

*Octanol/phosphate buffer pH 7.4.

\section{Methods}

The Institutional Review Boards of both the University of Texas Health Science Center at San Antonio and the University of Illinois College of Medicine at Chicago provided approval before initiation of this study. It was an open label, nonrandomized study that was conducted as the initial evaluation of the clinical effectiveness and safety of this new drug for brachial plexus block. Included in the study were 32 ASA physical status I or II adult patients scheduled to undergo upper extremity surgery under brachial plexus anaesthesia. Written informed consent was obtained and morphine $0.15 \mathrm{mg} \cdot \mathrm{kg}^{-1}$ IM and midazolam 0-3.0 mg IV were given for premedication. Each patient received a subclavian perivascular block according to the technique described by Winnie. ${ }^{5}$ Following elicitation of appropriate paraesthesia one group of patients ( $n=15$ ) received 0.5 per cent ropivacaine without epinephrine and a second group ( $n=$ 17) received 0.5 per cent ropivacaine with epinephrine in a concentration of 1:200,000. Thirty-three $\mathrm{ml}$ of the anaesthetic solution was utilized for the subclavian perivascular block, and an additional $5 \mathrm{ml}$ was used to block the intercostobrachial nerve in the axilla.

Evaluation of sensory and motor function was carried out prior to the block and at 2, 5, 10, 15, 20, 25 and $30 \mathrm{~min}$ following the block, then every $15 \mathrm{~min}$ until five hours post-block, every $30 \mathrm{~min}$ until $12 \mathrm{hr}$ post-block, and every hour until complete recovery. Sensory block was assessed in the $\mathrm{C}_{2}$ through $\mathrm{T}_{2}$ dermatomes and graded such that $0=$ no loss of sensation to pinprick, $1=$ analgesia (patient feels touch but not pain) and 2 = anaesthesia (patient does not feel touch). Motor block was assessed at the shoulder by asking the patient to elevate the arm while keeping the elbow straight and at the hand by grip strength, with $0=$ no weakness, 1 = paresis, and $2=$ paralysis. In addition, patients were monitored constantly for any signs of cardiovascular or central nervous system toxicity (changes in blood pressure, heart rate or rhythm, signs or symptoms of CNS stimulation). Values are expressed \pm SD. Data were analyzed using Chi square and Fisher's exact test, Wilcoxon rank sum test, and two-way analysis of variance with $P<0.05$ considered statistically significant.

\section{Results}

Characteristics of the two groups are presented in Table II, which indicates no significant differences in age, height, weight, female to male ratio or dose of local anaesthetic. Table III tabulates the heart rate, and systolic and diastolic blood pressure prior to the block and for the first $30 \mathrm{~min}$ thereafter, and indicates that these variables did not change significantly following either ropivacaine 0.5 per cent or ropivacaine 0.5 per cent with epinephrine. The quality of sensory block, as determined by the percentage of patients developing analgesia and anaesthesia in each dermatome, is represented in Figures 2 and 3. The percentage of patients at each brachial plexus $\left(\mathrm{C}_{5}\right.$ through $T_{1}$ ) dermatome developing analgesia was 93 per cent or greater (Figure 2) and the percentage developing analgesia was 87 per cent or greater. In the distribution of the cervical plexus, $C_{2}$ through $C_{4}$, fewer patients developed analgesia and anaesthesia (Figures 2 and 3). 
TABLE II Patient characteristics and dose of drug used

\begin{tabular}{llllll}
\hline Drug & $\begin{array}{l}\text { Age } \\
(\mathrm{yr})\end{array}$ & $\begin{array}{l}\text { Height } \\
(\mathrm{cm})\end{array}$ & $\begin{array}{l}\text { Weight } \\
(\mathrm{kg})\end{array}$ & $\begin{array}{l}\text { Sex } \\
(F / M)\end{array}$ & $\begin{array}{l}\text { Dose } \\
\left(\mathrm{mg} \cdot \mathrm{kg}^{-1}\right)\end{array}$ \\
\hline $\begin{array}{l}\text { Ropivacaine 0.5\% } \\
(n=15)\end{array}$ & $43.9 \pm 11.3$ & $170.5 \pm 9.1$ & $77.3 \pm 13.4$ & $2 / 13$ & $2.5 \pm 0.5$ \\
$\begin{array}{l}\text { Ropivacaine 0.5\% } \\
\text { with epincphrine } \\
(n=17)\end{array}$ & $44.0 \pm 12.8$ & $172.8 \pm 7.9$ & $74.4 \pm 9.4$ & $1 / 16$ & $2.6 \pm 0.3$ \\
\hline
\end{tabular}

TABLE III Heart rate and blood pressure

\begin{tabular}{|c|c|c|c|c|c|c|c|c|}
\hline & $\begin{array}{l}\text { Control } \\
\text { injection }\end{array}$ & $2 \min$ & $5 \min$ & $10 \mathrm{~min}$ & $15 \mathrm{~min}$ & $20 \mathrm{~min}$ & $25 \min$ & $30 \mathrm{~min}$ \\
\hline \multicolumn{9}{|l|}{ Heart rate } \\
\hline Ropivacaine $0.5 \%$ & $77.9 \pm 11.8$ & $77.2 \pm 12.8$ & $76.5 \pm 12.0$ & $75.3 \pm 11.7$ & $74.5 \pm 11.9$ & $76.0 \pm 10.6$ & $74.0 \pm 10.0$ & $73.5 \pm 10.0$ \\
\hline \multicolumn{9}{|l|}{ Ropivacaine $0.5 \%$} \\
\hline with epinephrine & $70.2 \pm 15.5$ & $73.0 \pm 15.0$ & $73.4 \pm 15.1$ & $73.8 \pm 15.3$ & $74.0 \pm 14.8$ & $74.4 \pm 15.7$ & $74.5 \pm 15,3$ & $72.3 \pm 15.7$ \\
\hline \multicolumn{9}{|l|}{ Systolic BP } \\
\hline Ropivacaine $0.5 \%$ & $134.4 \pm 17.3$ & $134.3 \pm 16.1$ & $134.9 \pm 16.5$ & $133.3 \pm 18.5$ & $133.3 \pm 15.7$ & $133.4 \pm 16.2$ & $132.4 \pm 17.0$ & $131.2 \pm 19.0$ \\
\hline $\begin{array}{l}\text { Ropivacaine } 0.5 \% \\
\text { with epinephrine }\end{array}$ & $130.7 \pm 12.0$ & $132.7 \pm 13.6$ & $131.4 \pm 16.6$ & $131.0 \pm 15.7$ & $131.4 \pm 17.2$ & $130.5 \pm 16.5$ & $130.3 \pm 15.9$ & $128.1 \pm 16.6$ \\
\hline \multicolumn{9}{|l|}{ Diastolic BP } \\
\hline Ropivacaine $0.5 \%$ & $83.5 \pm 10.6$ & $82.8 \pm 8.3$ & $82.7 \pm 9.0$ & $83.5 \pm 10.3$ & $83.5 \pm 8.8$ & $82.3 \pm 7.7$ & $82.1 \pm 8.3$ & $81.3 \pm 9.4$ \\
\hline $\begin{array}{l}\text { Ropivacaine } 0.5 \% \\
\text { with epinephrine }\end{array}$ & $83.2 \pm 8.4$ & $80.5 \pm 8.1$ & $79.4 \pm 8.8$ & $78.1 \pm 9.3$ & $79.2 \pm 10.4$ & $79.5 \pm 9.8$ & $79.7 \pm 8.2$ & $79.7 \pm 10.2$ \\
\hline
\end{tabular}

There was no difference between the ropivacaine 0.5 per cent and ropivacaine 0.5 per cent with epinephrine groups in terms of the percentage of patients developing analgesia or anaesthesia.

The time required for the onset of analgesia and anaesthesia is summarized in Table IV. Although the mean time to the onset of analgesia and anaesthesia appeared to be shorter in several dermatomes in the ropivacaine 0.5 per cent with epinephrine group, these differences were not statistically significant. In view of the large variability in onset times, median values are also listed in Table IV. The median analgesia onset time was five minutes and the median anaesthesia onset time ranged from 15 to $25 \mathrm{~min}$. The duration of the sensory block provided by ropivacaine may be seen in Table $\mathrm{V}$. The duration of analgesia at $T_{2}$ and anaesthesia at $C_{7}, C_{8}$, and $T_{1}$ was significantly shorter in the ropivacaine 0.5 per cent with epinephrine group. The duration of analgesia and anaesthesia was not significantly different between the two groups in the remaining brachial plexus dermatomes. Again, because of the large variability in duration, the median values are also listed in Table $\mathrm{V}$. The median duration of analgesia ranged from 718 to $892 \mathrm{~min}$ (11.9 to $14.9 \mathrm{hr}$ ) and the median duration of anaesthesia ranged from 465 to $732 \mathrm{~min}$ ( 7.8 to $12.2 \mathrm{hr}$ ). The time required for the initial onset of sensory block at any dermatome level and the final resolution of sensory block are summarized in Table VI. These times, which did not differ significantly between groups, demonstrated a rapid initial onset of sensory block (a mean of less than four minutes for analgesia) with a prolonged duration (a mean greater than $13 \mathrm{hr}$ for analgesia). The number of dermatomes anaesthetized over time is displayed graphically in Figure 4, which indicates that the rapidity of spread of the local anaesthetic is not significantly changed by the addition of epinephrine.

The quality of motor block, as determined by the percentage of patients developing paresis and paralysis at the shoulder and hand, was profound, with 100 per cent of patients in both groups developing paresis at both the shoulder and hand. Paralysis at the shoulder was also noted in 100 per cent of patients in both groups and at the hand was noted in 93 per cent of patients in the ropivacaine 0.5 and 94 per cent of patients in the ropivacaine 0.5 per cent with epinephrine group. Table VII, which lists the times required for the onset and the duration of the motor block, also demonstrates a rapid initial onset (a mean of three minutes for shoulder paresis) and a prolonged duration (a mean of 755 to $777 \mathrm{~min}$ (12.6-12.9 hr) for shoulder paresis). There was no difference between groups in onset or duration of motor block. 


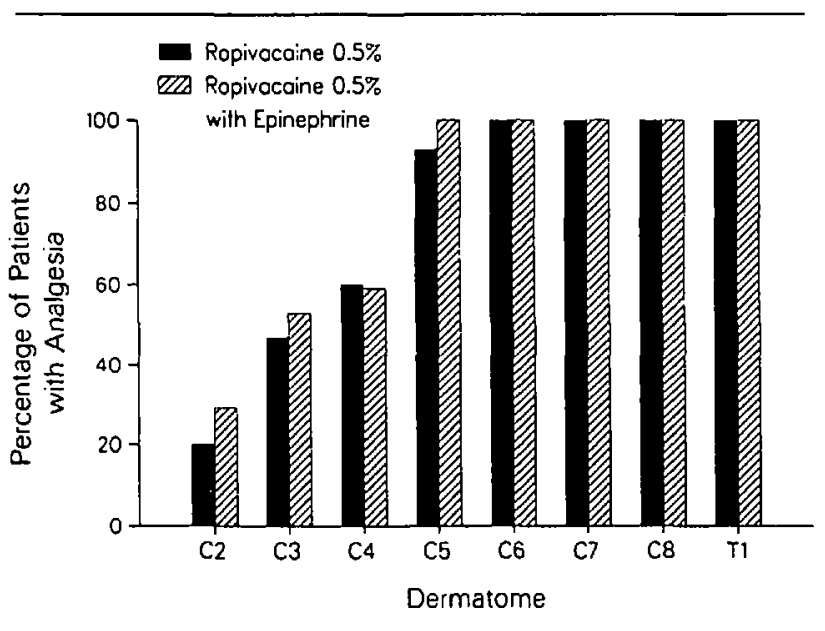

FIGURE 2 Analgesia was achieved in $\geq 93$ per cent patients in the $C_{5}$ through $T$, dermatomes.

There was one technical failure in the ropivacaine 0.5 per cent with epinephrine group.

\section{Discussion}

The present study has demonstrated that ropivacaine 0.5 per cent is an effective agent for brachial plexus anaesthesia, producing anaesthesia of the $C_{5}$ to $T_{1}$ brachial plexus dermatomes in 87 per cent or more of the patients in our study. For hand surgery it is generally necessary to block the $\mathrm{C}_{6}, \mathrm{C}_{7}$, and $\mathrm{C}_{8}$ dermatomes and this was achieved in 100 per cent of our patients. Besides an effective sensory

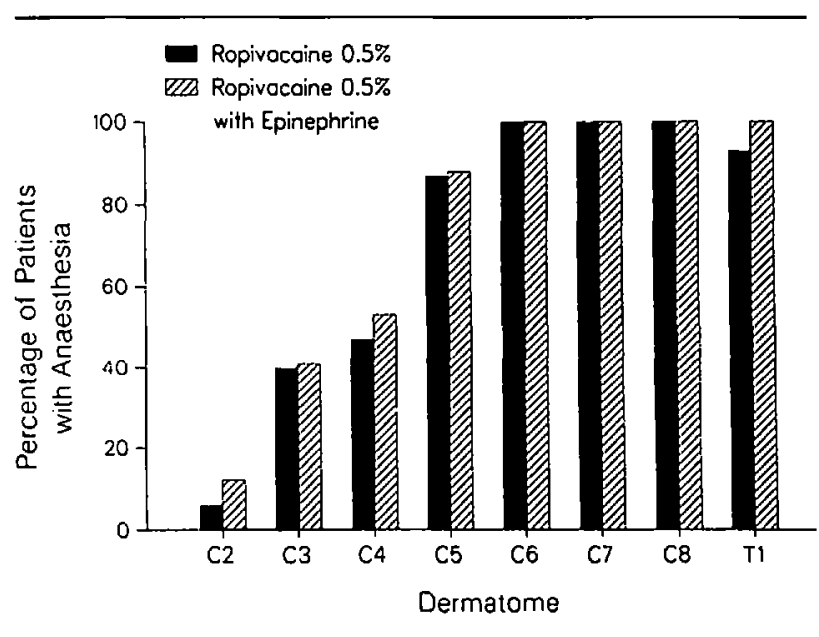

FIGURE 3 The percentage of patients at each brachial plexus $\left(C_{5}\right.$ through $T_{1}$ ) dermatome developing anaesthesia was $\geq 87$ per cent while fewer patients developed anaesthesia of the cervical plexus $\left(C_{2}, C_{3}, C_{4}\right)$

block, we noted that a profound motor block also developed, the onset and duration of which were similar to that of the sensory block. The motor block resulting from ropivacaine utilized for brachial plexus anaesthesia in the present study is in contrast to that resulting from the same drug utilized for epidural anaesthesia as observed by Thompson et al. ${ }^{6}$ and Concepcion et al. ${ }^{7}$ who reported that only a minimal motor block accompanied the sensory changes produced by 0.5 per cent ropivacaine. It is

TABLE IV Time to onset of sensory block (min)

\begin{tabular}{|c|c|c|c|c|c|}
\hline & $C_{s}$ & $C_{6}$ & $C_{7}$ & $C_{8}$ & $T_{1}$ \\
\hline \multicolumn{6}{|l|}{ Analgesia } \\
\hline \multicolumn{6}{|l|}{ Ropivacaine $0.5 \%$} \\
\hline mean $\pm S D$ & $18.4 \pm 31.9$ & $8.1 \pm 8.8$ & $14.0 \pm 24.0$ & $6.5 \pm 6.4$ & $6.3 \pm 5.0$ \\
\hline median & 5.0 & 5.0 & 5.0 & 5.0 & 5.0 \\
\hline lower, upper quartile & $2.0,21.3$ & $2.0,10.0$ & $2.0,10.0$ & $2.0,10.0$ & $2.0,10.0$ \\
\hline \multicolumn{6}{|l|}{$\begin{array}{l}\text { Ropivacaine } 0.5 \% \\
\text { with epinephrine }\end{array}$} \\
\hline mean $\pm S D$ & $10.3 \pm 8.8$ & $6.2 \pm 3.9$ & $6.3 \pm 4.5$ & $7.4 \pm 6.5$ & $13.5 \pm 31.6$ \\
\hline median & 5.0 & 5.0 & 5.0 & 5.0 & 5.0 \\
\hline lower, upper quartile & $2.0,17.5$ & $2.0,10.0$ & $2.0,10.0$ & $2.0,10.0$ & $2.0,10.0$ \\
\hline \multicolumn{6}{|l|}{ Anaesthesia } \\
\hline \multicolumn{6}{|l|}{ Ropivacaine $0.5 \%$} \\
\hline mean \pm SD & $61.3 \pm 120.3$ & $25.5 \pm 19.4$ & $32.8 \pm 34.1$ & $35.5 \pm 40.5$ & $25.7 \pm 23.8$ \\
\hline median & 20.0 & 20.0 & 25.0 & 15.0 & 17.5 \\
\hline lower, upper quartile & $12.5,52.5$ & $10.0,45.0$ & $15.0,30.0$ & $10.0,60.0$ & $8.8,45.0$ \\
\hline \multicolumn{6}{|l|}{$\begin{array}{l}\text { Ropivacaine } 0.5 \% \\
\text { with epinephrine }\end{array}$} \\
\hline mean $\pm S D$ & $22.0 \pm 11.5$ & $15.9 \pm 6.4$ & $16.6 \pm 7.8$ & $25.7 \pm 30.3$ & $25.8 \pm 32.1$ \\
\hline median & 20.0 & 15.0 & 20.0 & 15.0 & 15.0 \\
\hline Jower, upper quartile & $15.0,30.0$ & $10.0,20.0$ & $10.0,20.0$ & $12.5,30.0$ & $7.5,27.5$ \\
\hline
\end{tabular}


TABLE V Duration of sensory block (min)

\begin{tabular}{|c|c|c|c|c|c|}
\hline & $C_{5}$ & $C_{6}$ & $C_{7}$ & $C_{8}$ & $T_{1}$ \\
\hline \multicolumn{6}{|l|}{ Analgesia } \\
\hline \multicolumn{6}{|l|}{ Ropivacaine $0.5 \%$} \\
\hline mean $\pm S D$ & $739.6 \pm 227.0$ & $857.1 \pm 163.3$ & $842.3 \pm 183.5$ & $824.6 \pm 153.2$ & $831.8 \pm 149.2^{*}$ \\
\hline median & 718.0 & 885.0 & 892.5 & 838.0 & 892.5 \\
\hline lower, upper quartile & $582.5,898.0$ & $682.0,1015.8$ & $685.8,1015.0$ & $715.8,955.0$ & $710.5,955.0$ \\
\hline \multicolumn{6}{|l|}{$\begin{array}{l}\text { Ropivacaine } 0.5 \% \\
\text { with epinephrinc }\end{array}$} \\
\hline mean $\pm S D$ & $745.0 \pm 214.0$ & $779.1 \pm 178.4$ & $754.3 \pm 168.8$ & $758.5 \pm 165.9$ & $688.9 \pm 234.5^{*}$ \\
\hline median & 765.0 & 770.0 & 775.0 & 770.0 & 685.0 \\
\hline lower, upper quartile & $590.0,896.5$ & $652.5,895.0$ & $622.5,808.0$ & $661.5,864.0$ & $564.0,831.5$ \\
\hline \multicolumn{6}{|l|}{ Anaesthesia } \\
\hline \multicolumn{6}{|l|}{ Ropivacaine $0.5 \%$} \\
\hline mean $\pm S D$ & $434.8 \pm 254.6$ & $700.6 \pm 202.1$ & $714.1 \pm 216.9^{*}$ & $664.9 \pm 193.8^{*}$ & $640.7 \pm 146.3^{*}$ \\
\hline median & 499.0 & 692.5 & 732.5 & 707.5 & 640.0 \\
\hline lower, upper quartile & $231.3,586.3$ & $512.5,896.3$ & $618.3,896.3$ & $539.5,792.5$ & $568.8,712.5$ \\
\hline \multicolumn{6}{|l|}{$\begin{array}{l}\text { Ropivacaine } 0.5 \% \\
\text { with epinephrine }\end{array}$} \\
\hline mean $\pm S D$ & $484.0 \pm 213.0$ & $614.1 \pm 162.9$ & $582.2 \pm 180.7^{*}$ & $539.0 \pm 171.9^{*}$ & $468.3 \pm 175.0^{*}$ \\
\hline median & 465.0 & 585.0 & 555.0 & 485.0 & 465.0 \\
\hline lower, upper quartile & $345.0,705.0$ & $500.0,722.5$ & $450.0,665.0$ & $437.5,680.0$ & $367.5,530.0$ \\
\hline
\end{tabular}

*P<0.05.

possible that if a lower concentration of ropivacaine had been utilized for the brachial plexus block, a differential block might have been produced similar to that produced by 0.5 per cent ropivacaine injected epidurally, but further studies are necessary to confirm this.

The mean onset of analgesia in the $C_{6}$ through $T_{1}$ dermatomes was $14 \mathrm{~min}$ or less, while the mean onset of

TABLE VI Time required for initial onset and final resolution of sensory block regardless of dermatome (minutes)

\begin{tabular}{lll}
\hline & Onset & Duration \\
\hline $\begin{array}{l}\text { Analgesia } \\
\begin{array}{l}\text { Ropivacaine 0.5\% } \\
\text { mean } \pm \text { SD }\end{array}\end{array}$ & $3.1 \pm 2.3$ & $\begin{array}{l}896.9 \pm 136.3 \\
(14.9 \pm 2.3 \mathrm{hr})\end{array}$ \\
$\begin{array}{l}\text { Ropivacaine 0.5\% } \\
\text { with epinephrine } \\
\text { mean } \pm \text { SD }\end{array}$ & $3.9 \pm 3.1$ & $\begin{array}{l}834.4 \pm 178.4 \\
(13.9 \pm 3.0 \mathrm{hr})\end{array}$ \\
$\begin{array}{l}\text { Anaesthesia } \\
\begin{array}{l}\text { Ropivacaine 0.5\% } \\
\text { mean } \pm \text { SD }\end{array}\end{array}$ & $16.1 \pm 17.6$ & $\begin{array}{l}747.0 \pm 167.0 \\
(12.5 \pm 2.8 \mathrm{hr})\end{array}$ \\
$\begin{array}{l}\text { Ropivacaine 0.5\% } \\
\text { with epinephrine } \\
\text { mean } \pm \text { SD }\end{array}$ & $11.4 \pm 6.8$ & $\begin{array}{l}674 \pm 170.1 \\
(11.2 \pm 2.8 \mathrm{hr})\end{array}$ \\
\hline
\end{tabular}

anaesthesia was approximately $30 \mathrm{~min}$ (see Table IV). A slower onset of blockade of both modalities was seen at $\mathrm{C}_{5}$, probably because the injection was made directly caudad (away from $\mathrm{C}_{5}$ ) low in the interscalene grove.

We found that epinephrine did not reduce the onset time for analgesia, anaesthesia, or motor block. The duration of sensory block was found to be changed significantly by epinephrine at $T_{1}$ for analgesia and at $C_{7}, C_{8}$, and $T_{1}$ for anaesthesia. The duration of sensory block in the remaining brachial plexus dermatomes as well as the duration of motor block was not effected by epinephrine. This is in contrast to most local anaesthetics in which epinephrine reduces the onset and prolongs the duration of anaesthesia. This effect of epinephrine is presumably due to its vasoconstricting properties, which result in a decrease in vascular absorption that allows more anaesthetic molecules to reach and remain at the nerve membrane. ${ }^{8}$ The fact that we did not see any benefit from the addition of epinephrine may be due to the fact that ropivacaine, unlike bupivacaine, mepivacaine, or lidocaine, had intrinsic vasoconstricting properties. This was demonstrated recently by Kopacz et al. ${ }^{9}$ who found that unlike bupivacaine, which produced cutaneous vasodilatation, ropivacaine produced vasoconstriction and a reduction of cutaneous blood flow. Thus, when they added epinephrine to both agents, it had no effect when added to ropivacaine but produced a significant reduction in blood 
TABLE VII Onset and duration of motor block (min)

\begin{tabular}{|c|c|c|c|c|}
\hline & $\begin{array}{l}\text { Onset at } \\
\text { shoulder }\end{array}$ & $\begin{array}{l}\text { Onset at } \\
\text { hand }\end{array}$ & $\begin{array}{l}\text { Duration at } \\
\text { shoulder }\end{array}$ & $\begin{array}{l}\text { Duration at } \\
\text { hand }\end{array}$ \\
\hline \multicolumn{5}{|l|}{ Paresis } \\
\hline \multicolumn{5}{|l|}{ Ropivacaine $0.5 \%$} \\
\hline mean $\pm S D$ & $3 \pm 1$ & $8 \pm 7$ & $777 \pm 230$ & $832 \pm 152$ \\
\hline median & 2 & 5 & 778 & 828 \\
\hline lower, upper quartile & 2,5 & 2,10 & 678,956 & 718,951 \\
\hline \multicolumn{5}{|l|}{$\begin{array}{l}\text { Ropivacaine } 0.5 \% \\
\text { with cpincphrine }\end{array}$} \\
\hline mean $\pm S D$ & $3 \pm 2$ & $8 \pm 7$ & $755 \pm 190$ & $723 \pm 184$ \\
\hline median & 2 & 5 & 775 & 705 \\
\hline lower, upper quartile & 2,5 & 2,13 & 613,867 & 535,888 \\
\hline \multicolumn{5}{|l|}{ Paralysis } \\
\hline \multicolumn{5}{|l|}{ Ropivacaine $0.5 \%$} \\
\hline mean $\pm S D$ & $12 \pm 9$ & $30 \pm 21$ & $574 \pm 213$ & $613 \pm 158$ \\
\hline median & 10 & 23 & 635 & 615 \\
\hline lower, upper quartile & 5,20 & 15,45 & 397,703 & 533,688 \\
\hline \multicolumn{5}{|l|}{$\begin{array}{l}\text { Ropivacaine } 0.5 \% \\
\text { with epinephrine }\end{array}$} \\
\hline mean $\pm S D$ & $11 \pm 8$ & $20 \pm 13$ & $548 \pm 167$ & $505 \pm 186$ \\
\hline median & 10 & 20 & 490 & 438 \\
\hline lower, upper quartile & 5,20 & 11,29 & 444,633 & 381,681 \\
\hline
\end{tabular}

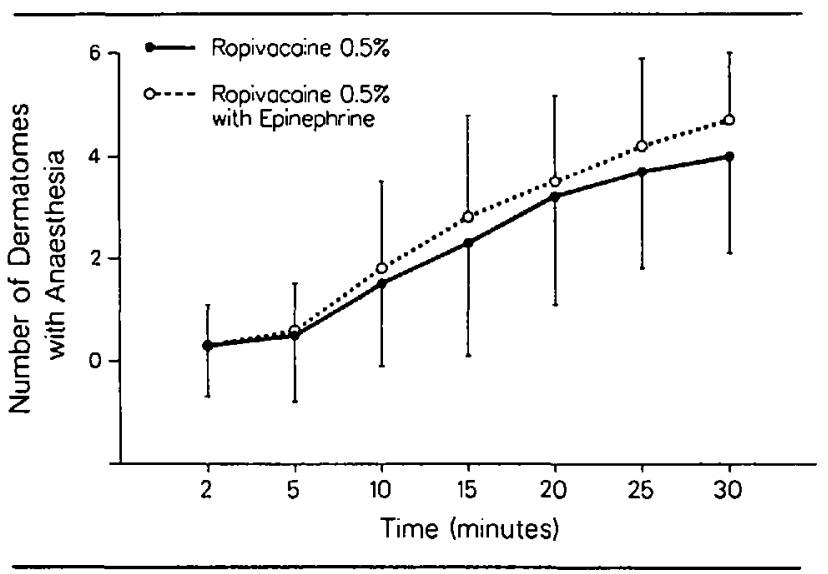

FIGURE 4 The number of dermatomes anaesthetized over time (an indicator of rapidity of spread of the local anaesthetic), was not different between the ropivacaine 0.5 per cent and ropivacaine 0.5 per cent with epinephrine groups.

flow when added to bupivacaine. From these studies one could predict that the addition of epinephrine to ropivacaine would have less effect on its onset and duration; a prediction corroborated by the present study.

Comparisons of the data obtained in the present study with ropivacaine with other studies with bupivacaine are likely to be misleading as the sensory and motor endpoints used to determine onset and duration vary among investi- gators. Whether the anaesthetic profile or ropivacaine offers any clinical advantage can only be answered by double-blind comparative studies and such studies are currently underway at both the University of Texas and the University of Illinois

However, the theoretical advantage of ropivacaine over bupivacaine is its lesser potential for cardiotoxicity, which has been demonstrated in several animal models. Moller $e t$ al. found that the effect of ropivacaine on the transmembrane action potential variables of cardiac muscle was greater than lidocaine but less than bupivacaine ${ }^{10}$ and Reiz et al. demonstrated that when ropivacaine was injected into the left anterior descending coronary artery of anaesthetized animals, its electrophysiological toxicity was intermediate between lidocaine and bupivacaine. Arthur et al. also reported that although plasma concentrations of ropivacaine and bupivacaine associated with conclusions were similar, bupivacaine was associated with a greater number of ventricular arrthymias and death. "We did not see any evidence of cardiovascular or central nervous system toxicity with a mean dose of $2.5-2.6 \mathrm{mg} \cdot \mathrm{kg}^{-1}$ of ropivacaine. Heart rate, systolic and diastolic blood pressure were not significantly changed after injection with either the plain solution or with that to which epinephrine was added.

Ropivacaine is being evaluated as a replacement for bupivacaine. The present study indicates that ropivacaine 
0.5 per cent, even without epinephrine, provides excellent sensory and motor blockade of prolonged duration. If comparative studies indicate that it is at least as effective as bupivacaine, then ropivacaine may replace bupivacaine because of its decreased toxicity.

\section{References}

1 Rosenberg $P H$, Heinonen $E$. Differential sensitivity of $A$ and $C$ nerve fibres to long-acting amide local anaesthetics. Br J Anaesth 1983; 55: 163-7.

2 Akerman B, Hellberg IB, Trossvik C. Primary evaluation of the local anaesthetic properties of the amino amide agent ropivacaine (LEA 103). Acta Anaesthesiol Scand 1988; 32: 571-8.

3 Feldman HS, Covino BG. Comparative motor-blocking effects of bupivacaine and ropivacaine, a new amino amide local anesthetic, in the rat and dog. Anesth Analg 1988; 67: 1047-52.

4 Reiz S, Haggmark S, Johansson G, Nath S. Cardiotoxicity of ropivacaine - a new amide local anaesthetic agent. Acta Anaesthesiol Scand 1989; 33: 93-8.

5 Winnie AP. Perivascular techniques of brachial plexus block. In: Winnie AP (Ed.). Plexus Anaesthesia.

Philadelphia: WB Saunders 1983; 145-63.

6 Thompson GE, Brown DL, Carpenter RL. An initial study of ropivacaine for epidural anaesthesia. Anesth Analg 1989; 68: S290.

7 Concepcion M, Arthur GR, Steele SM, Bader AM, Covino $B G$. A new local anaesthetic, ropivacaine. Its epidural effects in humans. Anesth Analg 1990; 70: 80-5.

8 Covino BG. Clinical pharmacology of local aesthetic agents. In: Cousins MJ, Bridenbaugh PO (Eds.). Neural Blockade, Philadelphia: JB Lippincott, 1988; 117.

9 Kopacz DJ, Carpenter RL, Mackey DC. Effect of ropivacaine on cutaneous capillary blood flow in pigs. Anesthesiology 1989; 71: 69-74.

10 Moller RA, Covino BG. Cardiac electrophysiologic effects of a new long acting local aesthetic agent (LEA-103). Anesthesiology 1986; 65: A183.

11 Feldman HS, Arthur GR, Covino BG. Comparative systemic toxicity of convulsant and supraconvulsant doses of intravenous ropivacaine, bupivacaine, and lidocaine in the conscious dog. Anesth Analg 1989; 69: 794-801. 